\title{
TAX LEGISLATION IN THE REAGAN ERA-MOVEMENT TO OR FROM A CONSUMPTION BASE?
}

\author{
Charles O. Galvin*
}

I

INTRODUCTION

The burden of this paper is to discuss and to contrast the essential features of an accretion system and a consumption system for determining taxable income and the policy implications of each system. As a principle of national policy, we should opt for one or the other, but not mix them in a hybrid form, both because of the complexities a hybrid produces and because of the resulting unfairness in the system.

\section{II}

\section{A Theoretical Analysis of the Accretion System}

\section{A. Components of a Pure System}

Economists express the accretion system by the formula: $I=A+C$, where $I$ (income) equals $A$ (savings or accretion in net worth) plus $C$ (consumption). If the factor $A$ is a negative, this denotes a reduction in net worth resulting from savings withdrawal or disinvestment. In a pure accretion system for determining taxable income the taxpayer's net assets would be inventoried at market value at the end of each taxable year. The difference between the net asset values at the beginning and end of the accounting period reflects the net accretion or decrement in monetary value of the taxpayer's command over consumption (the $A$ component). The consumption expenditures (the $C$ component) for the accounting period are added to the $A$ component to determine income. To illustrate:

Market value of taxpayer's net assets at the end of the period

Market value of taxpayer's net assets at the beginning of the period

Net accretion in market value during the period

Add: Expenditures for consumption during the year

Income 
This formula derives from the traditional Haig-Simons measure of income; ${ }^{1}$ it has been the subject of numerous discussions about tax policy. ${ }^{2}$ The Commissioner of Internal Revenue has described this principle in his annual report:

Economists generally agree that . . the ideal measure of income over a particular period of time . . . is the amount that the individual or family has consumed over that period plus the change in its net worth. ${ }^{3}$

From the beginning of the income tax system this concept has been the basis of what reformers describe as the "pure" accretion system. The present tax law falls short of the pure system in two important respects: first, it shelters certain income of the taxpayer by removing it from the taxable base ${ }^{4}$ and, second, it allows deductions for certain "consumption expenditures."5

\section{B. Advantages of a Pure System}

Economic data reflect that the aggregate national income tax base under a pure system would be more than twice that of the base under existing law. ${ }^{6}$ Therefore, approximately the same revenue could be collected with tax rates of $5.5 \%$ to $25 \%$ instead of the present $11 \%$ to $50 \%$, or alternatively, with a flat rate of $10 \%$ to $12 \%$.

A no-exception, no-modifications accretion system would tax each individual on current real economic income as defined in the previously

1. H. Simons, Personal Income Taxation 61-62, 206 (1938); Haig, The Concept of IncomeEconomic and Legal Aspects, in The Federal Income TaX 7 (R. Haig ed. 1921).

2. See, e.g., B. Bittker, C. Galvin, R. Musgrave \& J. Pechman, A Comprehensive Income Tax Base? A Debate (1968); Congressional Budget Office, Revising the Individual Income Tax 72 (1983); Fund for Public Policy Research, Reforming the Federal Tax Structure (1973); C. Galvin \& B. Bittker, The Income Tax: How Progressive Should It Be? (1969); J. Pechman, Comprehensive Income Taxation (1977); U.S. Dep'T of the Treas., Blueprints for Basic TaX Reform (1977); 3 Report of the Royal Comm'n on TAXation 39 (1966); American Bar Association, Section of Taxation, Special Committee on Simplification, Evaluation of the Proposed Model Comprehensive Income Tax, 32 TAx L. 563 (1979); Bittker, Reflections on Tax Reform, 47 U. CIN. L. REv. 185 (1978); Goode, The Economic Definition of Income, in M. McInTYRE, F. SANDER \& D. WestFall, Readings in Federal Taxation 3, 9-1 1 (2d ed. 1983); Graetz \& McDowell, Tax Reform 1985: The Quest for a Fairer, More Efficient and Simpler Income Tax, 3 YALE L. \& PoL'y REv. 10 (1985); Hettich, Henry Simons on Taxation and the Economic System, 32 NAT'L TAX J. 1 (1979).

3. U.S. Dep't of the Treas., Internal Revenue Service, 1982 Statistics of Income, Individual Income Tax Returns 101 (1984) [hereinafter cited as Statistics of Income].

4. E.g., I.R.C. \$ \& 101-134 (Lawyers Co-op. 1984 \& Supp. 1985) (providing for exclusions from gross income); id. \$\$ 401-425 (Lawyers Co-op 1983 \& Supp. 1985) (providing for deductions from income for amounts contributed to pension, profit-sharing, stock bonus plans or with respect to stock options).

5. E.g., I.R.C. \& 164 (Lawyers Co-op. $1974 \&$ Supp. 1985) (deduction for state and local taxes not related to trade or business or income producing activity); id. \& 165(c)(3) (Lawyers Co-op. Supp. 1985) (deduction for personal casualty losses); id. \& 170 (Lawyers Co-op. 1974 \& Supp. 1985) (deduction for charitable contributions); id. $\$ 213$ (Lawyers Co-op. Supp. 1985) (deduction for medical and dental expenses).

6. See generally American Bar Foundation \& Southern Methodist University, Studies in Substantive Tax Reform 33 (1969); Comm'n to Revise the Tax Structure, Reforming the Federal Tax Structure 56 (1973); Congressional Budget Office, Revising the Individual INCOME TAX xviii (1983). The data reflect that a modified expanded income that took into account only certain unrealized net gains and, therefore, was not a pure accretion system would, nevertheless, double the taxable base from $\$ 415$ billion to $\$ 882$ billion. Comm'N to Revise the Tax Structure, supra, at 56. 
described Haig-Simons formula. ${ }^{7}$ Many statutory provisions presently in the Internal Revenue Code could thereby be eliminated, such as those providing for exclusions from income,$^{8}$ deductions for various forms of consumption expenditures (e.g., personal interest and taxes, medical expenses, and charitable contributions), ${ }^{9}$ tax-free exchanges, ${ }^{10}$ corporate reorganizations, ${ }^{11}$ and capital gain-ordinary income distinctions. ${ }^{12}$ In addition, if full corporate integration were achieved, ${ }^{13}$ the complexities of Subchapter $\mathrm{C}$ of the Internal Revenue Code could be eliminated. Because all income would be reflected in current year dollars, the need for indexation would be minimized. Finally, as all accretions in wealth would be accounted for in the income tax system, there would be little or no. need for an estate and gift tax system.

\section{III}

\section{The Development of Tax Accounting Rules in Determining The $A$ Component-A Confused Trend Toward an ACGRETION SYSTEM}

The term "accretion" is one used by economists to describe the HaigSimons concept of income. It is not to be confused with the accrual system sanctioned under generally accepted accounting principles employed by accountants. ${ }^{14}$ The two concepts are, however, similar. The accrual system seeks to recognize all income as earned, less the expenses incurred to produce such income. Thus, expenses are matched against income in the accounting period during which economic activity takes place, irrespective of the inflow or outflow of cash. Yet, accrual accounting does not go so far as the pure accretion system in recognizing unrealized gains, although accrual accounting does recognize unrealized losses through the use of appropriate reserves.

The accounting profession maintains that the accrual basis measures business income correctly; yet tax rules have from the beginning also permitted taxpayers to use the cash receipts and disbursements basis of accounting. ${ }^{15}$ This system requires the accounting for income as it is constructively or actually received in cash or the equivalent of cash and the accounting for expenses as they are actually or constructively paid in cash or cash equivalent. This latter system has made possible certain abuses, however, as taxpayers could postpone recognition of income merely by deferring the collection of receipts, and they could accelerate deductions by paying expenses in advance. Accordingly, Congress has responded from time

7. H. Simons, supra note 1; Haig, supra note 1 .

8. E.g., I.R.C. $\$ \$ 101-134$ (Lawyers Co-op. 1974 \& Supp. 1985).

9. E.g., id. $\$ \S 163,164,170,213$ (Lawyers Co-op. 1984 \& Supp. 1985).

10. E.g., id. \$\& 1031-1042.

11. E.g., id. \&\$ 354-358, 368 (Lawyers Co-op. 1983 \& Supp. 1985).

12. E.g., id. \$\$ 1221-1223, $1231-1256$ (Lawyers Co-op. 1974 \& Supp. 1985)

13. See infra text accompanying notes 36-37.

14. See P. Grady, Inventory of Generally Accepted Accounting Princtples for Business ENTERPRISEs 100 (Accounting Research Study No. 7 1965).

15. See I.R.C. \& 446(c)(1) (Lawyers Co-op. 1983); Treas. Reg. \& 1.446-1(c)(i) (1985). 
to time by requiring taxpayers who might otherwise have used the cash basis either to convert to the accrual basis or to convert to the accrual basis for certain transactions. ${ }^{16}$ In the case of accrual basis taxpayers, on the other hand, the courts have treated such taxpayers as on a cash basis for certain transactions, that is, for example, cash collected in one period representing income to be earned in a later period is treated as income when received. ${ }^{17}$ The Congress has responded to some of these decisions by enacting remedial legislation for certain groups. ${ }^{18}$ Thus, the evolution of tax accounting rules by the Congress and the courts has blurred the distinction between the cash receipts and disbursements basis and the accrual basis. ${ }^{19}$

Despite this confusion, the enactment of an accretion system would not represent too great a legislative leap from present law. It could be accomplished by expanding the definition of adjusted gross income to include in full all unrealized gains and losses and by repealing the Code sections permitting exclusions from income. In addition, personal deductions such as those for medical expenses, charitable contributions, personal interest, and taxes (i.e., the $C$ component) would be disallowed.

The inclusion of unrealized gains and losses might have been regarded as a radical proposition in the past; yet, as the Staff of the Joint Committee on Taxation has recently commented, the Congress has moved towards taxing unrealized income, generally in areas where valuation and liquidity were not significant, the income was primarily attributable to sophisticated taxpayers, and the tax avoidance possibilities were serious. ${ }^{20}$ In particular, the Joint Committee pointed to the 1969 legislation that required inclusion in income of original issue discount on corporate bonds, ${ }^{21}$ the 1981 legislation requiring marked-to-market valuation of commodity futures contracts, ${ }^{22}$ and the 1984 legislation extending such treatment to many option transactions. ${ }^{23}$

16. See, e.g., I.R.C. $\$ 447$ (Lawyers Co-op. 1983) (requiring certain corporations engaged in farming to use the accrual basis); id. $\$ 461$ (b) (requiring cash basis taxpayers paying interest in advance to use the accrual basis for determining the amount of deduction).

17. Schlude v. Commissioner, 372 U.S. 128 (1963); American Auto. Ass'n v. United States, 367 U.S. 687 (1961); Automobile Club v. Commissioner, 353 U.S. 180 (1957).

18. E.g., I.R.C. $\$ 455$ (Lawyers Co-op. 1983) (providing for accrual basis treatment of prepaid subscription income for publishing houses); id. $\$ 456$ (providing for accrual basis treatment of prepaid dues in certain membership organizations); id. $\$ 458$ (providing for accrual basis treatment of returned magazines, paperbacks, and records in the case of dealers of such items).

19. In Thor Power Tool Co. v. Commissioner, 499 U.S. 522 (1979), the Supreme Court discussed the differences between tax accounting and financial accounting, noting that financial accounting tended to understate income in the interests of conservatism, whereas tax accounting required the recognition of income at the earliest possible time in order to meet the Treasury's objectives of efficient administration and collection of the tax. Id at 541 .

20. Joint Comm. on Taxation, 98th Cong., 2d Sess., Analysis of Proposals Relating to Comprehensive Tax Reform (Comm. Print 1984), reprinted in 25 Tax Notes 161, 172 (1984).

21. I.R.C. \& 1232 (repealed 1984).

22. Id. \& 1256(a) (Lawyers Co-op. Supp. 1985) (providing for the treatment of each "section 1256 contract" as if it were sold for its fair market value on the last business day of the taxable year). A "section 1256 contract" is now defined as any regulated futures contract, any foreign currency contract, any nonequity option, and any dealer equity option. Id. $\&$ 1256(b) (West Supp. 1985).

23. Id. $\$ 1256$. 


\section{A. Compromises in a Pure Accretion System to Achieve Practical Administration of the $A$ Component}

If taxpayers in all income brackets were required to value all net assets each year in order to determine income, the problems of compliance and administration would be substantial. Compromises could be adopted, however, to relieve most taxpayers of the annual valuation requirement without causing a serious distortion in the amount of income reportable under an accretion system. If the requirement applied only to the taxpayer who owned consumer durables (e.g., home, automobile, furnishings) of a value of $\$ 250,000$ or more, and who owned investments (stocks, bonds, vested interest in a qualified plan) of $\$ 100,000$ or more, a relatively small percentage of tax filers would make the annual valuation. This suggested compromise is proposed on the basis of an analysis of the Statistics of Income published by the Commissioner of Internal Revenue ${ }^{24}$ and the statistics with respect to wealth holding in the United States. ${ }^{25}$

Table 1 displays cumulatively for adjusted gross income brackets the number of returns, the aggregate adjusted gross income, taxable income, and tax. Table 2 compiles similar data for 1980-1981 noncumulatively by income brackets. These statistics reflect that, for $1982,94.3 \%$ of the filers reported adjusted gross incomes under $\$ 50,000$. Even when certain expanded income concepts are applied to this group, about 200,000 returns out of ninety million now reporting less than $\$ 50,000$ of adjusted gross income would then reflect more than $\$ 50,000$ of adjusted gross income. ${ }^{26}$ What these data indicate is that the vast majority of filers are in the middle, lower middle, or lower income brackets.

The overall savings rate is about $6 \%$ of personal income ${ }^{27}$ and for those under $\$ 50,000$ of adjusted gross income, one may reasonably assume that their principal investments are in a home, family automobile, furnishings, and personal effects of a value less than $\$ 250,000$ and stocks, bonds, cash values of life insurance and vested interests in qualified plans of a value less than $\$ 100,000$. This assumption is corroborated by the data in Table 3 which reflect that a total of 803,000 persons (less than $1 \%$ of the number filing annual income tax returns) hold gross assets having a value of $\$ 500,000$ or more. Therefore, under the suggested compromise approximately $95 \%$ of

24. Statistics of InCOME, supra note 3, at 4; see also Galvin, The Commissioner's Statistics of Income: Required Reading for Tax Reformers, 27 TAx NoTEs 945, 947 (1985). The statistics reflect that 94.3\% of returns report under $\$ 50,000$ of adjusted gross income. Because of the low savings rate (about six percent of personal income) the total wealth accumulation of this large sector of the filing group would be relatively small.

25. U.S. Dep't of Commerce, Bureau of the Census, Statistical Abstract of the United States 1984, at 445-82 (1984) [hereinafter cited as Statistical Abstract]. The statistics reflect that in 1976 only 803,000 persons held gross assets of $\$ 500,000$ or more. Id. at 479 . This number would be greater in 1985 but the rates to total population would not be significantly different.

26. Statistics of Income, supra note $\$$, at 104

27. Statistical ABSTRACt, supra note 25, at 455, 458. In 1982 disposable personal income was $\$ 2,177$ billion, of which $\$ 125$ billion, or $5.8 \%$, was saved. 
the annual tax return filers would be exempt from the annual valuation requirement. ${ }^{28}$

\section{TABLE 1}

\section{Analysis of Income Tax Returns by Selected Adjusted Gross \\ INCOME BRACKeTS CUMUlated fRom THE LOWEST \\ BRACKET TO $\$ 100,000$ A.G.I.-1982}

All Taxpayers:

Individual Tax Returns

1982

All returns

$95,337,432$

AGI (total)

$1,852,135,465$

TI (total)

$1,473,348,899$

Tax (total)

$276,077,369$

Percent of TI

19.2

Under \$10M AGI

Returns

AGI

TI

Tax

Percent of TI

Under $\$ 20 M$ AGI

Returns

AGI

TI

Tax

Percent of TI

Under \$50M AGI

Returns

AGI

TI

Tax

Percent of TI

Under \$100M AGI

Returns

AGI

TI

Tax

Percent of TI

Over \$100M AGI

Returns
AGI
TI
Tax
Percent of $T I$

34.0 million

172.1 billion

93.3 billion

6.9 billion

7.5

58.9 million

532.2 billion

375.3 billion

41.5 billion

11.1

89.9 million

1488.7 billion

1141.4 billion

178.3 billion

15.6

93.7 million

1728.0 billion 1329.0 billion 228.5 billion

17.2

$$
\begin{aligned}
& .74 \text { million } \\
& 147.9 \text { billion } \\
& 116.6 \text { billion } \\
& 47.5 \text { billion } \\
& 41.6
\end{aligned}
$$

$35.7 \%$ (of all returns) 9.2\% (of total AGI)

$6.5 \%$ (of total TI)

$2.5 \%$ (of total tax)

$61.8 \%$

$28.4 \%$

$26.0 \%$

$15.0 \%$

$94.3 \%$

$79.5 \%$

$79.0 \%$

$64.6 \%$

98.3\%

$92.1 \%$

$91.9 \%$

$82.8 \%$

$.8 \%$
$7.9 \%$
$8.1 \%$
$17.5 \%$

Source: U.S. Dep't of the Treas., Internal Revenue Service, 1982 Statistics of Income, Individual Income TaX Returns 2 (Table A), 4 (Table C), 37 (Table 1.1) (1984).

28. In $\mathbf{1 9 7 5}$ approximately 82 million returns were filed, $i d$ at $\mathbf{3 2 6}$. 


\section{TABLE 2}

\section{Analysis of Income Tax Returns by Selected Adjusted Gross INCOME BRACKETS-1980, 1981}

All Taxpayers:

\begin{tabular}{lc} 
Individual Tax Returns & $\underline{1980}$ \\
\cline { 1 - 2 } All returns & 93.9 million \\
AGI (total) & $1,613.7$ billion \\
TI (total) & $1,280.0$ billion \\
Tax (total) & 250.3 billion \\
Percent of TI & 20
\end{tabular}

1981

95.4 million $1,772.6$ billion $1,410.9$ billion 284.1 billion 20

$\$$ O-\$10M AGI

Returns $\quad 38.4$ million

AGI

TI

Tax

Percent of TI

186.4 billion

100.5 billion

8.4 billion

8.4

\$10-\$20M AGI

$40.9 \%$ (of all returns) $11.5 \%$ (of total AGI) $8.0 \%$ (of total TI) $3.4 \%$ (of total tax)

36.4 million 178.3 billion 97.0 billion

8.1 billion

$37.3 \%$ $10.0 \%$ $7.0 \%$ $2.8 \%$

Returns
AGI
TI
Tax
Percent of TI
$20-\$ 50 M$ AGI

Returns

AGI

TI

Tax

Percent of TI

25.4 million

370.4 billion 291.0 billion 39.9 billion 13.7

25.2 million

$28.8 \%$ $49.5 \%$ $51.4 \%$ $49.3 \%$ 3.9 billic 123.3 billion 19.2

$\$ 50-\$ 100 M$ AGI

Returns

AGI

TI

Tax

Percent of TI

Over $\$ 100 \mathrm{M} \mathrm{AGI}$

Returns
AGI
TI
Tax
Percent of TI

$\begin{array}{rr}2.6 \text { million } & 2.8 \% \\ 165.9 \text { billion } & 10.0 \% \\ 133.1 \text { billion } & 10.6 \% \\ 39.7 \text { billion } & 15.8 \% \\ 29.8 & \end{array}$

.55 million

91.7 billion

81.5 billion

39.0 billion

47.8 367.2 billion 288.5 billion 39.5 billion 13.7

29.7 million 904.7 billion 729.1 billion 142.2 billion 19.5

$26.4 \%$ $20.7 \%$ $20.4 \%$ $13.9 \%$

$31.1 \%$ $51.0 \%$ $51.6 \%$ $50.0 \%$

$\begin{array}{rr}3.4 \text { million } & 3.6 \% \\ 219.4 \text { billion } & 12.3 \% \\ 174.1 \text { billion } & 12.3 \% \\ 51.0 \text { billion } & 17.9 \%\end{array}$
29.2

$\begin{array}{rr}.65 \text { million } & .6 \% \\ 111.9 \text { billion } & 6.3 \% \\ 94.8 \text { billion } & 6.7 \% \\ 43.2 \text { billion } & 15.2 \%\end{array}$

Source: U.S. Dep't of the Treas., Internal Revenue Service, 1981 Statistics of Income, Individual Income Tax Returns 2 (Table A), 4 (Table C), 35 (Table 1.1) (1983). 
TABLE 3

Wealth Holding in the United States-1976

Top $1 \%$, or 2.2 million people, hold $20 \%$ of the wealth.

Persons holding gross assets

of more than $\$ 120,000$

$8,695,000$

Persons holding gross assets

of $\$ 120,001$ to $\$ 199,999$

$4,759,000$

Persons holding gross assets

of $\$ 200,000$ to $\$ 499,999$

$3,133,000$

Persons holding gross assets of $\$ 500,000$ to $\$ 999,999$

555,000

Persons holding gross assets

of at least $\$ 1,000,000$

248,000

Source: U.S. Dep't of Commerce, Bureau of the Census, Statistical abstract of the United States 1984479 (1984) (statistics for 1976).

\section{B. The Exempt Group and Compliance}

Because those filers in the exempt group would not be making an annual valuation of net assets, they should be permitted some appropriate annual cost recovery system. Thus, they could deduct depreciation under the Treasury's proposed Capital Cost Recovery System (CCRS), ${ }^{29}$ depletion under a cost method determined by units of recovery, and amortization on a straight-line basis. They could make an accounting, as they do now, for gains and losses on sales and other taxable dispositions, and in addition, they could be required to make an accounting for gains and losses on transfers by gift or at death. Accordingly, this compromise of the pure accretion system would be administrable and would assure that all lifetime and deathtime transfers would ultimately be accounted for on a marked-to-market principle.

\section{The Nonexempt Group and Compliance}

Although the nonexempt group, that is, those required to make annual valuation of net assets, would be only a small percentage of all filers, their problems of valuation and access to liquid funds to pay the tax could nonetheless be significant. A taxpayer with rapidly appreciating shares in a closely held corporation, a partnership interest in a real estate development, or an investment in an improving patent might have difficulty both in establishing values and paying the tax resulting from the unrealized appreciation. For taxpayers with a diverse portfolio of investments, the mechanics of valuation could be administered as follows:

(1) marketable securities would be valued at the end of the taxable year based on published quotations;

29. The President's Tax Proposals to the Congress for Fairness, Growth, and Simplictty 132-59 (1985) [hereinafter cited as Pres. Proposals]. 
(2) not readily marketable assets would be valued or accounted for at the taxpayer's election by any one of the following methods:

(a) independent appraisal;

(b) capitalization of earnings;

(c) average of comparable sales of similar property;

(d) await the event of sale, exchange, gift, or death, determine the amount of gain or loss, prorate such amount over the taxable years during which the taxpayer has held the asset, and determine the resulting deficiency or refund for each year; or

(e) apply methods (a), (b), or (c) every five or seven years and prorate the resulting gain or loss to the intervening periods. ${ }^{30}$

Although every asset would not be marked-to-market ${ }^{31}$ value each year, there would be either a recognition of unrealized gain or loss or an accounting for gain or loss at all lifetime or deathtime transfers. Thus, the objectives of an accretion system would be achieved in a practical, administrable way: income would be accounted for as earned and the opportunities for deferral of recognition of income or nonrecognition of income would be substantially eliminated.

IV

\section{The $C$ Component}

In a pure accretion system there would be no deduction for consumption expenditures (the $C$ component); the expanded adjusted gross income concept (the $A$ component) would become the taxable base. As in the case of the $A$ component, however, some compromises with respect to the $C$ component could be achieved without serious distortion.

\section{A. Effect on Nonitemizers}

Table 4 reveals that about $70 \%$ of present filers, mostly in middle and lower income brackets, ${ }^{32}$ do not itemize. If we assume that in an accretion system some form of personal exemption deduction and zero bracket amount would be continued from the present system, and if we assume that, in general, middle and lower income taxpayers would be in the exempt group of filers (those not required to make annual asset valuation), then the accretion system would operate in a manner substantially similar to the current tax system for the great majority of filers. Thus, most present nonitemizers would determine adjusted gross income under an expanded definition but

30. These are methods presently employed for determining valuations for estate and gift tax purposes.

31. The term "marked-to-market" is used because it is now part of Code language with respect to the requirement of valuation on the last day of the taxable year. I.R.C. \& 1256 (Lawyers Co-op. Supp. 1985).

32. In 1982, a total of $\$ 284.5$ billion was claimed in itemized deductions, of which $\$ 214.5$ billion, or $75 \%$, was claimed by taxpayers with adjusted gross incomes of $\$ 25,000$ or more. Statistics or Income, supra note 3 , at 8. 
would not make the market value accounting for assets except for lifetime and deathtime transfers. They would deduct some exemption deduction for themselves and dependents and determine tax liability at lower rates after allowing for a zero bracket amount.

TABLE 4

Percent of All Individual Returns with Itemized

DEDUCTIONS-1972-82

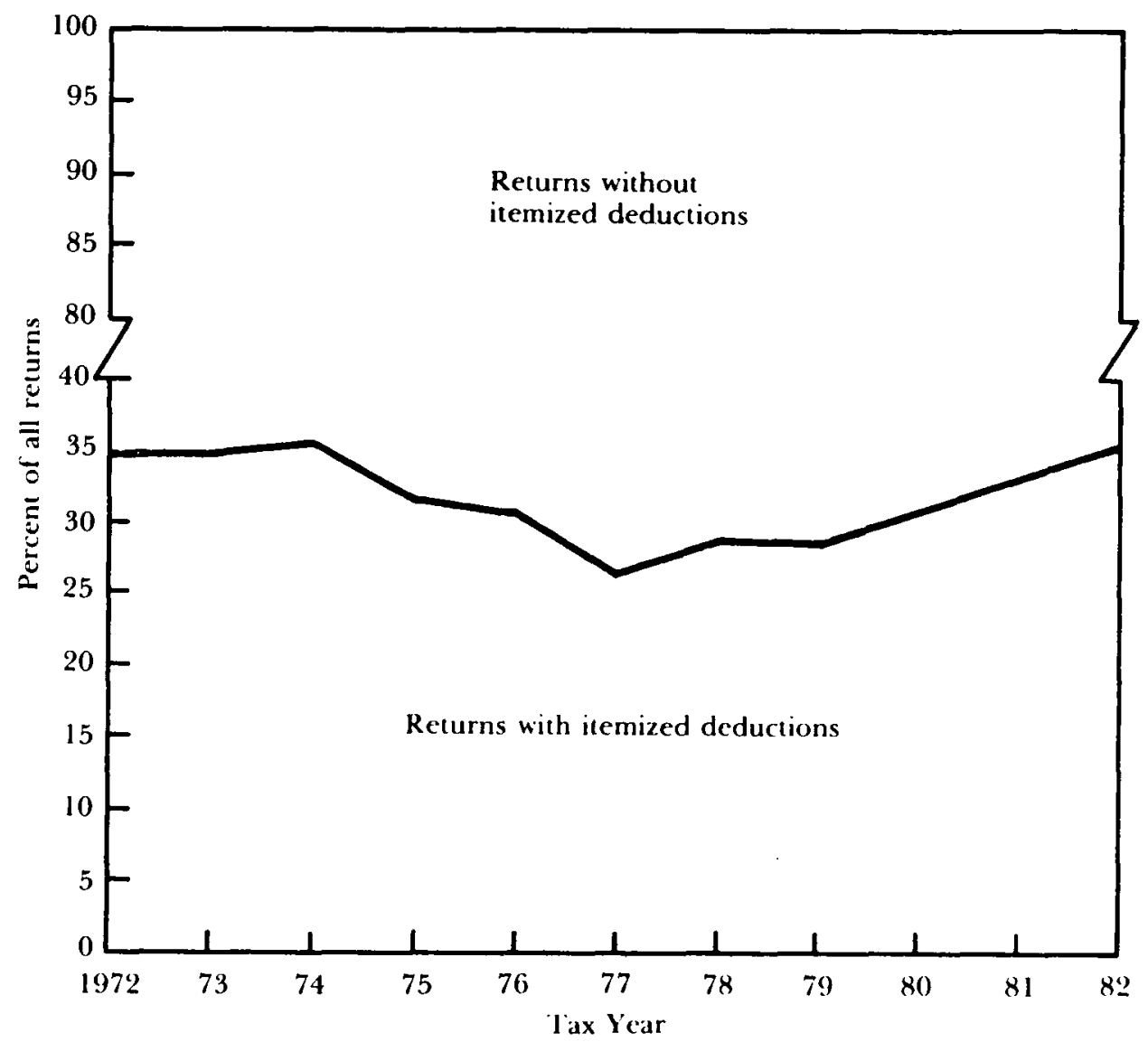

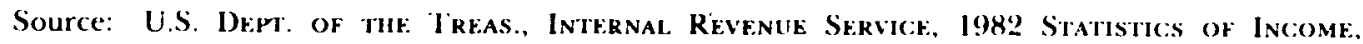
Individuat. InCOME IAX Returns 7 (1984).

\section{B. Effect on Itemizers}

Although consumption expenditures would not be deductible in a pure system, social policy and fairness would dictate in favor of allowing some adjustment for large involuntary expenditures such as extraordinary medical or casualty losses. A taxpayer who is drained of resources to meet some calamity experiences a reduction in net worth that can hardly be described as a routine living expense. In this connection, the recent enactment of 
legislation increasing the floor above which medical and personal casualty losses may be deducted ${ }^{33}$ and the President's recent proposals to limit charitable contributions and interest deductions and to eliminate the deduction for state and local taxes are indicative of a greater acceptance of restricting deductions for consumption expenditures. ${ }^{34}$

Each compromise made with respect to the deductibility of consumption expenditures significantly narrows the base, whether under the present law or an accretion system. Even among the $30 \%$ who itemize, the amounts deducted are substantial:

\section{Deductions in Billions}

1. Nonbusiness interest

$\$ 121.8$

2. Nonbusiness taxes

88.0

3. Charitable contributions

33.5

4. Medical and dental

21.7

5. Other (including casualty losses)

19.4

Total

$\$ 284.4^{35}$

Thus, a proposal must strike the delicate balance of recognizing certain deductible expenses while not dangerously reducing revenue.

\section{$\mathrm{V}$}

\section{An Overview of the Accretion System}

Table 5 explains the $\$ 1.8$ trillion gap between gross national product and taxable income. A modified accretion system as described above would narrow this gap and could be practically administered; it would more nearly reflect an aggregate tax base consistent with gross national product and national income.

\section{TABLE 5}

ReCONCILIATION OF GNP and TAXABLE INCOME-1982

(IN BILLIONS OF DOLLARS)

Item Amount

Gross national product (GNP) $\ldots \ldots \ldots \ldots \ldots \ldots \ldots \ldots \ldots \ldots \ldots \ldots \ldots \ldots \ldots \ldots \ldots \ldots, 0 \ldots \ldots .3$

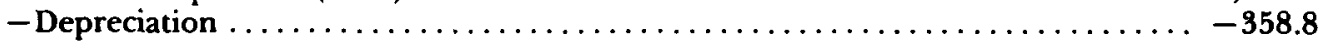

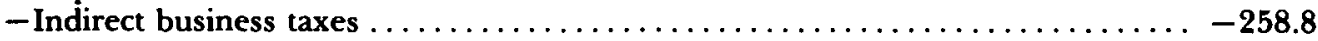

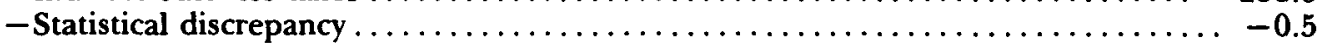

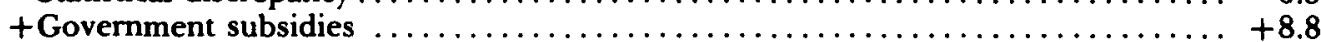

- Corporate retained earnings and corporate income tax $\ldots \ldots \ldots \ldots \ldots \ldots \ldots .92 .6$

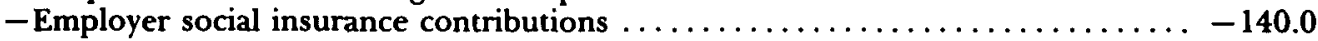

+ Net interest paid by government and consumers $\ldots \ldots \ldots \ldots \ldots \ldots \ldots \ldots \ldots+105.7$

33. See I.R.C. \& 213(a) (Lawyers Co-op. Supp. 1985) (effective in 1983, the floor on medical expenses was increased from 3\% to $5 \%$ ); id. $8165(\mathrm{~h})(2)$ (effective in 1983, the floor on personal casualty losses was increased from zero to $10 \%$ ).

34. Pres. Proposals, supra note 29, at 62, 70, 322.

35. Statistics of INCOME, supra note 3, at 60-61. 


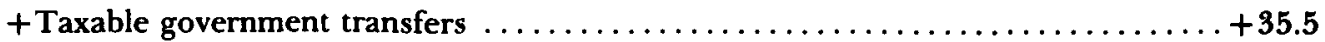

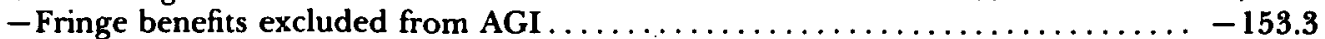

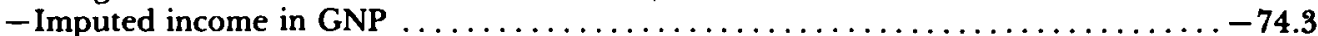

-Investment income of insurance companies and pension funds $\ldots \ldots \ldots \ldots \ldots \ldots-62.2$

-Investment income of nonprofit organizations and fiduciaries $\ldots \ldots \ldots \ldots \ldots \ldots . \mathbf{2 5 . 9}$

-Differences in accounting treatment between GNP and AGI $\ldots \ldots \ldots \ldots \ldots \ldots \ldots . \mathbf{3 0 . 9}$

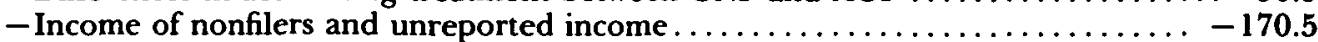

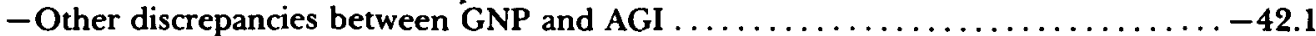

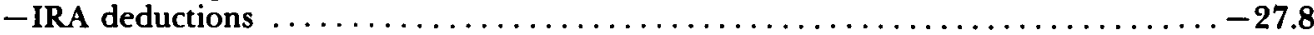

-Second-earner deduction . . . . . . . . . . . . . . . . .

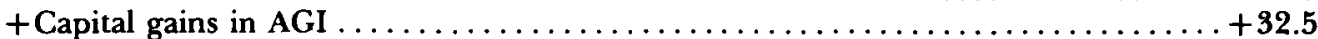

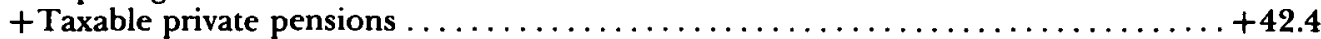

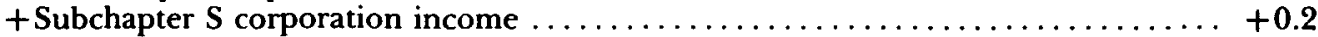

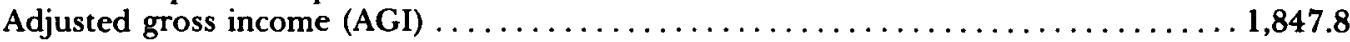

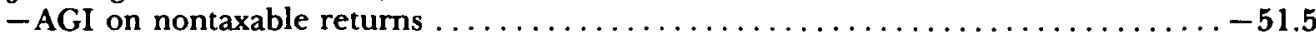

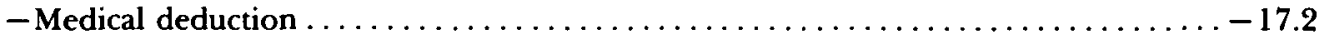

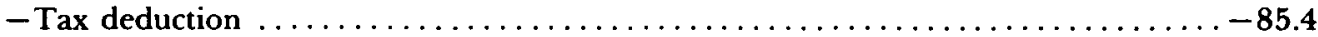

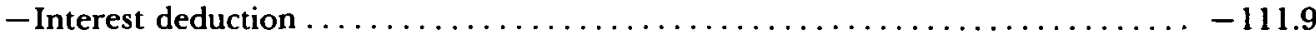

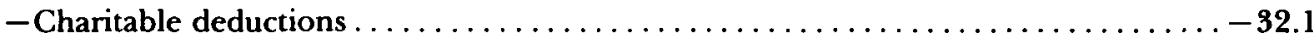

-Other deductions ................................... 18.0

+Floor under itemized deductions (zero bracket amount on itemizing returns) $\ldots+100.0$

-Personal exemptions ................................ -190.7

Taxable income on taxable returns (net of deficits) $\ldots \ldots \ldots \ldots \ldots \ldots \ldots \ldots \ldots, \mathbf{1 , 4 4 1 . 0}$

-Deduction equivalent of tax credits (estimated) $\ldots \ldots \ldots \ldots \ldots \ldots \ldots \ldots \ldots \ldots \ldots \ldots \ldots \ldots, 21.2$

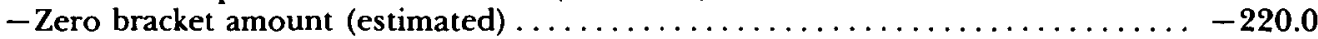

Tax base (estimated) $\ldots \ldots \ldots \ldots \ldots \ldots \ldots \ldots \ldots \ldots \ldots \ldots \ldots \ldots \ldots \ldots \ldots \ldots \ldots \ldots \ldots \ldots \ldots, 19.8$

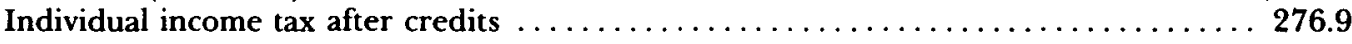

Sources: Survey of Current Business, July 1984; Statistics of Income: SOI Bulletin, Winter 1983-84 and Spring 1984, Internal Revenue Service; and staff estimates, reprinted in Staff of Jt. Comm. on Tax., Analysis of Proposals Relating to Comprehensive Tax Reform, 25 TAX Notes 161, 164 (1984).

\section{A. The Effect on Individuals}

In a broadened base, as suggested above, taxpayers in the upper income brackets would in general pay proportionately more taxes because net unrealized appreciation, presently excluded income, and presently deductible consumption expenditures would become part of the taxable base. Some additional revenue would be raised in the middle income brackets more or less proportionately throughout the group because of the expanded income base. The lower income brackets, whose income is from salaries and wages and who would be in the group exempt from making annual valuations, would determine income approximately as they do now.

\section{B. The Effect on Corporations}

An accretion system could function with a separate corporation tax, but the combination of two systems, one for individuals and one for corporations, would result in onerous double taxation. If $X$ Corporation's assets appreciate in value from $100 x$ to $110 x$, that factor would be reflected in the greater value of its stock. A shareholder of $X$ would inventory his stock at the greater value, so that the factor of appreciation at the corporate level would appear contemporaneously in both the incomes of the corporation and the shareholder. Both reinvested corporate earnings and distributed corporate 
earnings would be accounted for by the shareholder in the expanded income concept of an accretion system. Therefore, there would be little reason for imposing additional taxes at the corporate level. In practical terms, the trend of recent tax policy has been in the direction of eliminating the corporate tax. In 1960 the corporate income tax constituted $23 \%$ of tax revenues. ${ }^{36}$ For fiscal 1986 that percentage is expected to drop to $9 \% .{ }^{37}$

In order to protect the revenue, corporations would be required to withhold some tax for their shareholders so that shareholders receiving dividends and accounting for gains and losses in stock values could rely on such withholding credits for liquidity in meeting their individual tax liabilities.

\section{The Effect on Exempt Organizations}

If a modified accretion system were adopted and corporate taxes were eliminated, various exempt organizations holding corporate shares should be accountable in some manner for such investments; otherwise, the stream of corporate income passing to the exempt group would escape tax altogether. A solution would be to impose an excise tax on investment income, similar to the present excise tax imposed on investment income of private foundations. ${ }^{38}$ Investment income would also include unrealized gains and losses. Accordingly, an exempt organization with contributions that are received and expended would have no tax; an exempt organization that invests and reinvests its surplus funds in restricted or unrestricted endowment accounts would incur some excise tax on its investment income.

\section{The Estate and Gift Tax System}

If all accretions to wealth through gifts, devises, bequests and inheritances are included in income, there would be little reason for an estate and gift tax system, except perhaps on the transfer of the very largest accumulations of wealth.

\section{VI}

\section{Additional Areas Requiring Consideration}

\section{A. Moving Average}

Using a modified accretion system for all taxpayers would mean that income reported will tend to follow the ups and downs of the consumer price index or some other inflation index. In order to level out hills and valleys of annual income, taxpayers would use a moving average of five years, that is, income for 1984 would be averaged with 1980-1983, 1985 with 1981-1984,

36. J. Pechman, Federal Tax Policy 352 (4th ed. 1983).

37. Executtve Office of the President, Office of Management and Budget, The United States Budget in Brief, Fiscal Year 1986, at 66 (1985) [hereinafter cited as United States BUDGET IN Brigf]. Total revenues are projected at $\$ 793.7$ billion; corporate income taxes are estimated at $\$ 74.1$ billion, or $9.33 \%$.

38. See I.R.C. 84940 (Lawyers Co-op. 1980 \& Supp. 1985). 
and so on. This would avoid the effect of unusual peaks and valleys in net worth evaluation on a particular date. Of course, in order to preclude averaging for many taxpayers whose incomes are relatively constant, a floor could be established, as at present, below which no averaging would be required or permitted. ${ }^{39}$

\section{B. The System's Applicability to Foreign Taxpayers}

Aliens, both resident and nonresident, would be required to conform to the same rules as apply to United States citizens. Treaty arrangements presently extant could be modified to require proper reporting of gains and losses in value of marketable securities and periodic reporting, as suggested previously, on the changes in values of assets not susceptible of ready valuation.

\section{VII}

\section{The Consumption System}

As the formulation of the accretion system described above is expressed: $I$ (income) $=A$ (accretion in wealth) $+C$ (consumption), so the consumption system may be expressed: $I$ (income) $=C$ (consumption). Thus, in a consumption system, savings or investment fall outside the taxable base. The taxpayer's income is measured only by that amount which he consumed during the period. ${ }^{40}$ For most taxpayers the accounting for income and the administration of the system would be similar to that of an accretion system. Income from personal services would be accounted for as under present law. Amounts set aside each year in investments would be deducted in determining taxable income. The accounting for investments would be maintained in a qualified account similar to an unlimited individual retirement account under present law; the taxpayer would account for gains and losses in, and income from, investments in this account. As withdrawals were made for living expenses, the qualified account balance would be reduced, and the taxpayer's taxable income would be increased. Thus, a taxpayer could have income from two principal sources: personal services and withdrawals from the qualified account. As taxpayers moved through their most productive years, they would tend to build up the amounts in their qualified accounts, and in their later years would tend to withdraw amounts from such accounts.

Expenditures for consumer durables, e.g., home, automobile, furnishings, recreation vehicle, could be handled in one of several ways:

The consumer durable would be treated as any other form of savings and deducted from taxable income. A dollar limitation would be put on these transactions in the aggregate so that taxpayers acquiring luxury homes, luxury

39. See id. \$\& 1301-1305 (Lawyers Co-op. $1974 \&$ Supp. 1985).

40. The 1977 Treasury analysis of a consumption tax is in U.S. DEP'T OF THE TREAS., Blueprints for Basic TAX Reform 113-43 (1977) [hereinafter cited as Blueprints for Basic TaX Reform]. For further analysis, see Graetz, Implementing a Progressive Consumption Tax, 92 Harv. L. Rev. 1575 (1979). 
cars, vacation cottages, and the like would be required to treat the amount of consumer durables above a certain minimum as nondeductible ordinary consumption and, therefore, part of the taxable base.

Another alternative would be to exclude some part of the acquisition of consumer durables from the taxable base but to require the taxpayer to treat the use of such items as consumed income over some period of useful life. For example, in the case of a home financed by a $20 \%$ down payment and a thirty-year mortgage, the payments on the debt service each year could be the measurement of consumption value. This amount would not be deductible and would thus be part of the taxable base. This alternative would be applied to those consumer durables having an acquisition cost above a certain minimum. Thus, a taxpayer with a home, car, and personal effects having a cost below a reasonable minimum would deduct the acquisition cost and exclude the value of the use of such items from the taxable base.

A final alternative would deny any deduction for the entire acquisition cost of all consumer durables. They would be treated as any other living expense. Thereafter, the taxpayer would not be required to make any accounting for use value or cash received on sale.

\section{A. The Consumption System in Operation}

For the vast majority of taxpayers in the middle and lower income brackets for whom labor is the principal source of income and for whom the opportunity to set aside savings is minimal, compliance with a consumption system would vary little from the present system.

For taxpayers in the higher income brackets with substantial capital and income from capital, the taxable base would generally be reduced as they would deduct transfers to a qualified account for investments and the income therefrom. In this connection, several factors would have to be considered: (a) it might be necessary to impose a sharp progressive tax on high levels of consumption for upper income brackets to offset the revenue loss from excluding investments from the base; ${ }^{41}$ (b) the estate and gift tax system would have to be strengthened; otherwise, wealthy taxpayers could pass their investments in qualified accounts to their heirs who would retain them in their own qualified accounts free of tax accountability until withdrawals were made.

\section{B. Comparison with the Present System}

The present system follows the consumption system in many respects. Table 6, compiled from the Commissioner's Statistics, reflects the fact that sweat-of-the-brow income-salaries, wages, commissions, etc.-now comprises about $90 \%$ of adjusted gross income. The balance consists of dividends, interest, rents, royalties, gains from asset sales, and other capital income. Moreover, with tax shelters, maximum contributions to pension, profit sharing, and company sponsored savings and thrift plans, the high

41. Graetz, supra note 40 , at 1581-82. 
bracket taxpayer can now achieve the results of a quasi-consumption tax system. Therefore, the loss in revenue of a pure consumption system as contrasted with the present hybrid system would not be great. ${ }^{42}$ Moreover, advocates of a consumption system would contend that such a system offers opportunities for major capital formation, greater gross national product, and greater prosperity. ${ }^{43}$

TABLE 6

An Analysis of Personal Service Income as a Percentage of Adjusted Gross InCOME

\begin{tabular}{|c|c|c|c|}
\hline & 1980 & 1981 & 1982 \\
\hline $\begin{array}{l}\text { Number of returns } \\
\text { Taxable } \\
\text { Nontaxable }\end{array}$ & $\begin{array}{l}94 \text { million } \\
74 \text { million } \\
20 \text { million }\end{array}$ & $\begin{array}{l}95.4 \text { million } \\
76.7 \text { million } \\
18.7 \text { million }\end{array}$ & $\begin{array}{l}95.3 \text { million } \\
77.0 \text { million } \\
18.3 \text { million }\end{array}$ \\
\hline $\begin{array}{l}\text { Percent of returns reflecting no tax } \\
\text { Percent of returns itemizing deductions }\end{array}$ & $\begin{array}{l}21.3 \% \\
31 \%\end{array}$ & $\begin{array}{l}19.6 \% \\
33.1 \%\end{array}$ & $\begin{array}{l}19.2 \% \\
34 \%\end{array}$ \\
\hline $\begin{array}{l}\text { AGI total } \\
\text { Salaries and wages } \\
\text { Percent to total AGI }\end{array}$ & $\begin{array}{l}1,613 \text { billion } \\
1,350 \text { billion } \\
83.7 \%\end{array}$ & $\begin{array}{l}1,772 \text { billion } \\
1,486 \text { billion } \\
83.9 \%\end{array}$ & $\begin{array}{l}1,852 \text { billion } \\
1,565 \text { billion } \\
84.5 \%\end{array}$ \\
\hline $\begin{array}{l}\text { Other "sweat-of-the-brow" income: } \\
\text { Business and profession income } \\
\text { Pension income }\end{array}$ & $\begin{array}{l}55.1 \text { billion } \\
43.3 \text { billion }\end{array}$ & $\begin{array}{l}53.0 \text { billion } \\
53.8 \text { billion }\end{array}$ & $\begin{array}{l}50.5 \text { billion } \\
60.1 \text { billion }\end{array}$ \\
\hline Total other sweat-of-the-brow & 98.4 billion & 106.8 billion & 110.6 billion \\
\hline Total all personal service & $\begin{array}{l}1,448.4 \text { billion } \\
(89+\%)\end{array}$ & $\begin{array}{l}1,592.8 \text { billion } \\
(89+\%)\end{array}$ & $\begin{array}{l}1,675.6 \text { billion } \\
(90+\%)\end{array}$ \\
\hline
\end{tabular}

Source: U.S. Dept. of the Treas., Internal Revenue Service, 1982 Statistics of Income, INDIVIDUAL INCOME TAX RETURNS 4 (1984).

\section{Value-Added Tax}

The value-added tax (VAT) is another form of consumption tax that places a premium or surcharge on consumption. It has been the subject of considerable national attention since the early seventies. ${ }^{44}$ If one assumes

42. In 1977, the Treasury estimated that to obtain the same revenues, the rates under a consumption system would have to be $2 \%$ higher. Blueprints for Basic Tax Reform, supra note 40 , at $162,169$.

43. Galper, Tax Policy, in Setting National Priorities, The 1984 Budget 188-89 (J. Pechman ed. 1984).

44. 3 U.S. Dep't of the Treas., Tax Reform for Fairness, Simplicity, and Economic Growth (1984) (the pros and cons of a VAT are the subject of the volume); A.B.A. Section of Taxation, Report of the Special Comm. on the Value-Added Tax [hereinafter cited as Special Comm. on VAT], The Choice Between Value-Added and Sales Taxation at Federal and State Levels in the United States, 29 TAx L. 457 (1976); Special Comm. on VAT, Evaluation of an Additive-Method Value-Added Tax for Use in the United States, 30 TAX L. 565 (1977); Special Comm. on VAT, Report of the Special Subcommittee of the Committee on General Income Tax Problems on the Value-Added Tax, 24 TAx L. 419 (1971); Special Comm. on VAT, Should the United States Adopi the Value-Added Tax? -A Survey of the Policy Considerations and the Data Base, 26 TAx. L. 45 (1972); Special Comm. on VAT, Technical Problems in Designing a Broad-Based Value-Added Tax for the United States, 28 TAx L. 193 (1975); Galvin, It's VAT Time Again, 21 TAX Notes 275 (1983); Galvin, The Value-Added Tax-A Proposal for the 80's, 7 PePPERdine L. Rev. 505 (1980); 
that consumption of goods and services in the United States is about $\$ 2$ trillion, then a broad based VAT of, say, $10 \%$ could produce revenues of $\$ 200$ billion. Such a tax would be regressive, adding, in effect, an extra surcharge on those incomes below $\$ 50,000$, because those incomes now are expended almost entirely in consumption. Therefore, a VAT layered on an existing income tax system would require some credit for the VAT paid for lower income taxpayers. Alternatively, the necessities of food, clothing, housing, and medicine could be excluded from the VAT base, but as Table 7 demonstrates, the principal items of consumption expenditures are housing, food, and clothing, and their elimination would substantially narrow the VAT base. Furthermore, if necessities were removed from the VAT base, the highest bracket taxpayers would benefit proportionately more because of their accustomed higher standard of living. Accordingly, a broad based VAT with a credit for lower income taxpayers would be preferable.

As Congress seeks further revenue, the trend is to increase excises on alcohol, tobacco, motor fuel, and other selected items. Rather than impose excises selectively on particular items, it would be more equitable to employ the VAT.

\section{VIII \\ The Present System-A Hybrid}

Section 61(a) of the Internal Revenue Code describes gross income as "all income from whatever source derived, ...." Standing alone and without more, this section, which echoes the language of the sixteenth amendment, would mandate a pure accretion system. As the law developed, however, Congress introduced measures, consistent with a consumption system, specially favoring capital investment, capital formation, and the income therefrom. Provisions for capital gains, percentage depletion, the deduction of intangible drilling and development costs, the deduction of mining exploration and development expenditures, the exclusion of interest on state and local government obligations have long been in the law as economic incentives.

These defections from a pure accretion system were given further impetus beginning with the Kennedy Administration through the introduction of

Turnier, Designing An Efficient Value Added Tax, 39 TAx L. REv. 435 (1984); see Tax Restructuring Act of 1979: Hearings on H.R. 5665 Before the Ways and Means Comm., 96th Cong., 1st Sess. 14-24 (1979) (statement of G. William Miller, Treasury Secretary), reprinted in 9 TAx Notes 561 (1979); Brannon, Is the Regressivity of the Value-Added Tax an Important Issue?, 9 TAx Notes 879 (1979); Brown, Chilly VAT Reception Doesn't Daunt Ullman, 9 TAx Notes 703 (1979); Kingson, VAT: It's Broccoli, Dear, 8 TAX Notes 283 (1979); McClure, Thoughts on a Value-Added Tax, 9 TAx Notes 539 (1979); Schenk, The Value-Added Tax as a Replacement for Part of the Corporate Income Tax, 9 Tax Notes 767 (1979); Tait, The Value-Added Tax: A World-Wide Problem or Solution?, 9 TAx Notes 611 (1979); Note, VAT Editorials, 9 TAx NoTEs 411 (1979); see also A. Andersen \& Co., Perspectives on the Value-Added Tax (1979); D. Smith, J. Webber \& C. Cerf, What You Should Know About the Value-Added Tax (1971); Cohen, Foreign Experience with the Value-Added Tax, 24 NaT'L TAx J. 399 (1971); Smith, Value-Added Tax: The Case For, 2 Harv. Bus. REv. 77 (1970); Surrey, The Value-Added Tax for the United States-A Negative View, 21 TAX EXecutTVE 151 (1968). 
TABLE 7

Personal Consumption Expenditures in Current and Constant (1972) Dollars: 1960-82

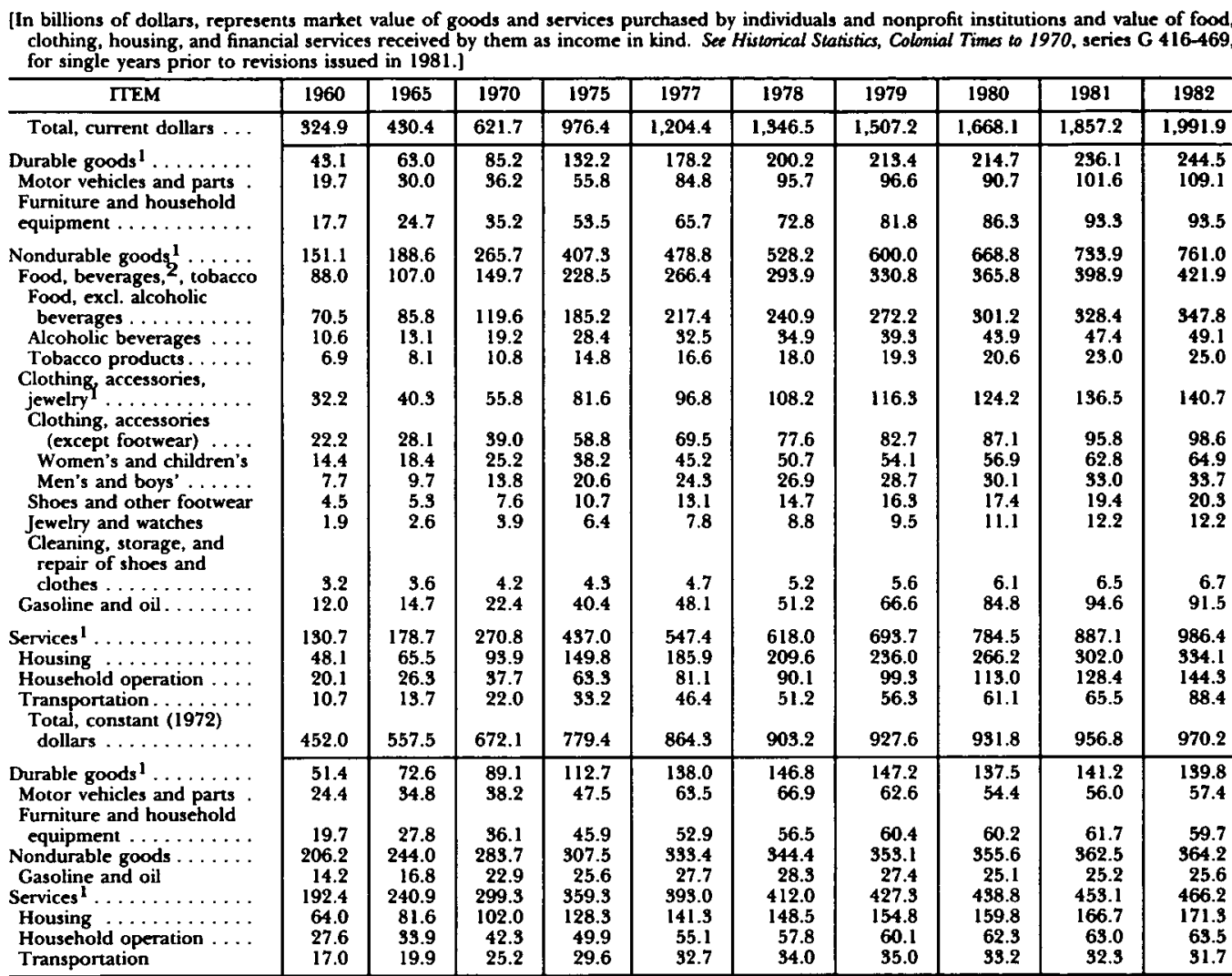

$1_{1}$ Includes items not shown separately. 2 Includes alcoholic and nonalcoholic beverages.

Source: U.S. Bureau of Economic Analysis, The National Income and Product Accounts of the United States, 1929-76, and Surven of Current Business, July 1983 .

investment credits, a direct dollar for dollar offset against tax liability to encourage capital investment. In the ensuing years Congress has responded with greater frequency to constituents' calls for help, and the tax law is now littered with special provisions partially or completely excluding from the taxable base income that would otherwise be taxable under section 61.45

The erosion of the accretion system became of sufficient concern that in the Budget Act of $1974^{46}$ Congress provided for an annual Tax Expenditure Budget (Table 8) to reflect the revenue impact of those particular provisions of the law that deviate from what would be a comprehensive tax on all income. Tax Expenditures have increased from $24.8 \%$ of federal revenues in 1971 to

45. For an excellent discussion of the rash of special interest legislation, see Calkins, $A$ Federal Income Tax Designed for Revenue Only, 23 Tax Notes 201, 203-05 (1984).

46. Pub. L. No. 93-344, 88 Stat. 297 (codified in scattered sections of title 31). 
$46 \%$ in $1984 .{ }^{47}$ The issue is, therefore, not an insubstantial one in national policy.

\section{TABLE 8}

\section{TAX EXPENDITURES by FunCtion, Fiscal YeARS 1982-84}

Millions of dollars

\begin{tabular}{|c|c|c|c|}
\hline Item & 1982 & 1983 & 1984 \\
\hline \multicolumn{4}{|l|}{ National defense } \\
\hline Exclusion of benefits and allowances to armed forces personnel & 2,890 & 2,780 & 2,820 \\
\hline $\begin{array}{l}\text { Exclusion of military disability pensions } \\
\text { International affairs }\end{array}$ & \multicolumn{2}{|c|}{ International affairs } & 160 \\
\hline Exclusion of income earned abroad by U.S. citizens & 1,850 & 2,155 & 2,165 \\
\hline Deferral of income of domestic international sales corporations & 2,870 & 2,565 & 2,000 \\
\hline Deferral of income of controlled foreign corporations & 520 & 560 & 605 \\
\hline \multicolumn{4}{|l|}{ General science, space, and technology } \\
\hline $\begin{array}{l}\text { Expensing of research and development expenditures } \\
\text { Credit for increasing research activities }\end{array}$ & 640 & 1,060 & 1,180 \\
\hline \multirow{2}{*}{\multicolumn{4}{|c|}{$\begin{array}{l}\text { Suspension of regulations relating to allocation under section } 861 \\
\text { of research and experimental procedures }\end{array}$}} \\
\hline & 100 & 220 & 110 \\
\hline \multicolumn{4}{|l|}{$\begin{array}{l}\text { Energy } \\
\text { Expensing of exploration and development costs }\end{array}$} \\
\hline \multicolumn{4}{|l|}{ Expensing of exploration and development costs } \\
\hline Oil and gas & $\mathbf{3 , 2 8 5}$ & 1,830 & 1,710 \\
\hline Other fuels & 45 & 45 & 50 \\
\hline \multicolumn{4}{|l|}{ Excess of percentage over cost depletion } \\
\hline Oil and gas & 3,065 & 2,545 & 2,295 \\
\hline Other fuels & 600 & 730 & 790 \\
\hline Capital gains treatment of royalties on coal & 310 & 275 & 295 \\
\hline \multicolumn{4}{|l|}{ Exclusion of interest on state and local government industrial } \\
\hline \multicolumn{4}{|l|}{ Residential energy credits } \\
\hline Supply incentives & 390 & 515 & 690 \\
\hline Conservation incentives & 435 & 400 & 390 \\
\hline \multicolumn{4}{|l|}{ Alternative, conservation and new technology credits } \\
\hline Supply incentives & 250 & 240 & 255 \\
\hline Conservation incentives & 290 & 155 & 100 \\
\hline Alternative fuel production credit & 20 & 45 & 70 \\
\hline Alcohol fuel creditb & 5 & 5 & 5 \\
\hline Energy credit for intercity buses & 10 & 15 & 15 \\
\hline \multicolumn{4}{|l|}{ Natural resources and environment } \\
\hline Expensing of exploration and development costs, nonfuel minerals & 85 & 90 & 100 \\
\hline Excess of percentage over cost depletion, nonfuel minerals & 595 & 640 & 690 \\
\hline Exclusion of interest on state and local government pollution & 870 & 1,020 & 1,150 \\
\hline \multicolumn{4}{|l|}{ Exclusion of payments in aid of construction of water, sewage, } \\
\hline Tax incentives for preservation of historic structures & 245 & 320 & 385 \\
\hline Capital gains treatment of iron ore & 40 & 40 & 40 \\
\hline Capital gains treatment of certain timber income & 565 & 730 & 910 \\
\hline \multicolumn{3}{|l|}{$\begin{array}{l}\text { Investment credit and seven-year amortization for reforestation } \\
\text { expenditures }\end{array}$} & 40 \\
\hline \multicolumn{4}{|l|}{ Agriculture } \\
\hline Expensing of certain capital outlays & 550 & $\mathbf{5 7 0}$ & 590 \\
\hline Capital gains treatment of certain income & 775 & 725 & 745 \\
\hline \multicolumn{4}{|l|}{$\begin{array}{l}\text { Deductibility of patronage dividends and certain other items of } \\
\text { cooperatives }\end{array}$} \\
\hline Exclusion of certain agricultural cost-sharing payments & 105 & 90 & 80 \\
\hline Commerce and housing credit & & & \\
\hline Dividend and interest exclusion & 1,530 & 615 & 605 \\
\hline $\begin{array}{l}\text { Exclusion of interest on state and local } \\
\text { bonds }\end{array}$ & 1,795 & 2,250 & 2,625 \\
\hline
\end{tabular}

47. Galper, supra note 43 , at 178 . 
Millions of dollars

\begin{tabular}{|c|c|c|c|}
\hline Item & 1982 & 1983 & 1984 \\
\hline Exemption of credit union income & 225 & 245 & 270 \\
\hline Excess bad debt reserves of financial institutions & 660 & 680 & 1,090 \\
\hline Exclusion of interest on life insurance savings & 6,625 & 6,780 & $7, \mathbf{3 1 0}$ \\
\hline Deductibility of interest on consumer credit & 10,900 & 10,710 & 10,530 \\
\hline Deductibility of mortgage interest on owner-occupied homes & 23,495 & 25,255 & 28,395 \\
\hline Deductibility of property tax on owner-occupied homes & 8,405 & $\mathbf{8 , 8 1 0}$ & 9,645 \\
\hline \multicolumn{4}{|l|}{ Exclusion of interest on state and local housing bonds for owner- } \\
\hline & 955 & 1,185 & 1,315 \\
\hline Depreciation on rental housing in excess of straight line & 565 & 705 & 82 \\
\hline \multicolumn{3}{|l|}{$\begin{array}{l}\text { Depreciation on buildings other than rental housing in excess of } \\
\text { straight line }\end{array}$} & 46 \\
\hline Capital gains (other than agriculture, timber, iron ore, and coal) & 26,590 & 22,865 & 23,46 \\
\hline Deferral of capital gains on home sales & 2,090 & 2,225 & 2,51 \\
\hline \multicolumn{2}{|l|}{$\begin{array}{l}\text { Exclusion of capital gains on home sales for persons aged } 55 \text { and } \\
\text { over }\end{array}$} & 765 & 86 \\
\hline Carryover basis of capital gains at death & 3,120 & $\mathbf{3 , 3 3 0}$ & 3,68 \\
\hline \multicolumn{4}{|l|}{ Investment credit, other than for ESOPs, rehabilitation of } \\
\hline structures, energy property, and reforestation expenditures & 19,255 & 17,170 & 18,32 \\
\hline Safe harbor leasing rules & 2,880 & $\mathbf{3 , 2 7 0}$ & 3,03 \\
\hline Accelerated depreciation on equipment other than leased property & 7,300 & 12,400 & 18,62 \\
\hline Amortization of start-up costs & 125 & 195 & 29 \\
\hline Exclusion of interest on certain savings certificates & 1,970 & 840 & 10 \\
\hline Reinvestment of dividends in public utility stock & 400 & 590 & 67 \\
\hline $\begin{array}{l}\text { Reduced rates on first } \$ 100,000 \text { of corporate income } \\
\text { Transportation }\end{array}$ & 12,290 & 13,195 & $14,93 !$ \\
\hline Deferral of tax on shipping companies & 25 & $\mathbf{3 5}$ & 4 \\
\hline \multicolumn{4}{|l|}{ Exclusion of interest on state and local government bonds for } \\
\hline \multicolumn{4}{|l|}{ Community and regional development } \\
\hline Five-year amortization for housing rehabilitation & 45 & 60 & 7 \\
\hline \multicolumn{4}{|l|}{ Investment credit for rehabilitation of structures (other than } \\
\hline historic) & 295 & 360 & 46 \\
\hline \multicolumn{4}{|l|}{ Education, training, employment, and social services } \\
\hline Exclusion of interest on state and local student loan bonds & 115 & 175 & 240 \\
\hline Parental personal exemption for students aged 19 or over & 1,065 & 985 & 94 \\
\hline Exclusion of scholarship and fellowship income & 465 & 415 & 37 \\
\hline Exclusion of employee meals and lodging (other than military) & 730 & 755 & 805 \\
\hline Employer educational assistance & 55 & 55 & 15 \\
\hline Exclusion of contributions to prepaid legal services plans & 20 & 25 & \\
\hline Investment credit for ESOPs & 2,455 & 2,220 & 2,405 \\
\hline Deduction for two-earner married couples & 1,005 & 5,685 & 10,040 \\
\hline Deductibility of charitable contributions (education) & 830 & 770 & 80 \\
\hline \multicolumn{4}{|l|}{ Deductibility of charitable contributions other than education and } \\
\hline & 7,550 & 7,085 & 7,17 \\
\hline Credit for child and dependent care expenses & 1,830 & 2,110 & 2,430 \\
\hline Exclusion of employer-provided child care & $\ldots$ & 10 & 30 \\
\hline \multicolumn{4}{|l|}{ Credit for employment of AFDC recipients and public assistance } \\
\hline recipients under work incentive programs & 30 & & \\
\hline General jobs credit & 115 & 35 & \\
\hline Targeted jobs credit & 360 & 495 & 705 \\
\hline Health & & & \\
\hline \multicolumn{4}{|l|}{ Exclusion of employer contributions for medical insurance } \\
\hline & 22,555 & 25,412 & 28,980 \\
\hline Deductibility of medical expenses & $\mathbf{3 , 9 7 0}$ & 2,950 & 2,635 \\
\hline Exclusion of interest on state and local hospital bonds & 730 & 925 & 1,115 \\
\hline Deductibility of charitable contributions (health) & 1,240 & 1,155 & 1,185 \\
\hline Tax credit for orphan drug research & $\cdots$ & 15 & 25 \\
\hline \multirow{2}{*}{\multicolumn{4}{|c|}{$\begin{array}{l}\text { Income secunty } \\
\text { Exclusion of social security benefits }\end{array}$}} \\
\hline & & & \\
\hline Disability insurance benefits & 1,770 & 1,675 & 1,660 \\
\hline OASI benefits for retired workers & 14,940 & 15,765 & 16,800 \\
\hline Benefits for dependents and survivors & $\mathbf{3 , 7 3 5}$ & $\mathbf{3 , 7 6 5}$ & $\mathbf{3 , 8 9 0}$ \\
\hline Exclusion of railroad retirement system benefits & 790 & 780 & 725 \\
\hline Exclusion of workmen's compensation benefits & 1,735 & 1,875 & 2,105 \\
\hline Exclusion of special benefits for disabled coal miners & 185 & 170 & 165 \\
\hline Exclusion of untaxed unemployment insurance benefits & 2,615 & $\mathbf{3 , \mathbf { 3 3 0 }}$ & 2,940 \\
\hline Exclusion of disability pay & 190 & 170 & 150 \\
\hline
\end{tabular}


Millions of dollars

\begin{tabular}{|c|c|c|c|}
\hline Item & 1982 & 1983 & 1984 \\
\hline Exclusion of public assistance benefits & 445 & 430 & 430 \\
\hline \multicolumn{4}{|l|}{ Net exclusion of pension contributions and earnings } \\
\hline $\begin{array}{l}\text { Employer plans } \\
\text { Plans for self-employed and others }\end{array}$ & $\begin{array}{r}65,805 \\
5,150\end{array}$ & $\begin{array}{r}70,005 \\
5,875\end{array}$ & $\begin{array}{r}78,780 \\
6,480\end{array}$ \\
\hline \multicolumn{4}{|l|}{ Exclusion of other employee benefits } \\
\hline Premiums on group term life insurance & 2,890 & 2,910 & 3,095 \\
\hline Premiums on accident and disability insurance & 165 & 160 & 160 \\
\hline $\begin{array}{l}\text { Income of trusts to finance supplementary and unemployment } \\
\text { benefits }\end{array}$ & 10 & 5 & 5 \\
\hline Additional exemption for the blind & $\mathbf{3 5}$ & $\mathbf{3 5}$ & 35 \\
\hline Additional exemption for the elderly & 2,385 & 2,360 & 2,420 \\
\hline Tax credit for the elderly & 135 & 135 & 185 \\
\hline Deductibility of casualty losses & 1,295 & 705 & 520 \\
\hline Earned-income credit ${ }^{*}$ & 460 & 390 & 340 \\
\hline Exclusion of interest on state and local bonds for rental housing & 425 & 580 & 770 \\
\hline Deduction for motor carrier operating rights & 115 & 115 & 115 \\
\hline Deduction for certain adoption expenses & 15 & 15 & 15 \\
\hline \multicolumn{4}{|l|}{ Veterans' benefils and services } \\
\hline Exclusion of veterans' disability compensation & 1,860 & 1,815 & 1,835 \\
\hline Exclusion of veterans' pensions & 330 & 305 & 295 \\
\hline Exclusion of GI bill benefits & 175 & 150 & 125 \\
\hline General government & & & \\
\hline $\begin{array}{l}\text { Credits and deductions for political contributions } \\
\text { General-purpose fiscal assitance }\end{array}$ & 185 & 195 & 295 \\
\hline Exclusion of interest on general-purpose state and local debt & 7,215 & 8,335 & 9,430 \\
\hline $\begin{array}{l}\text { Deductibility of nonbusiness state and local taxes other than on } \\
\text { owner-occupied homes }\end{array}$ & 19,085 & 20,000 & 21,755 \\
\hline $\begin{array}{l}\text { Tax credit for corporations receiving income from doing business } \\
\text { in U.S. possessions } \\
\text { Interest }\end{array}$ & 2,365 & 2,150 & 1,830 \\
\hline Deferral of interest on savings bonds & 315 & 450 & 500 \\
\hline
\end{tabular}

Sources: Special Analyses, Fiscal 1984, at G-26 to -28; and Tax Expenditures, at 20. All estimates have been rounded to the nearest $\$ 5$ million.

* Less than $\$ 5$ million.

a Outlay equivalent estimates.

b In addition, the exemption from the excise tax for alcohol funds results in a reduction of excise tax receipts of $\$ 55$ million in $1982, \$ 80$ million in 1983 , and $\$ 90$ million in 1984 .

c The figures in the table indicate the tax subsidies provided by the earned-income tax credit. The effect on outlays in $\$ 1,280$ million for $1982, \$ 1,205$ million for 1983 , and $\$ 1,125$ million for 1984 .

Reproduced in J. Pechman, Federal Tax Policy 344-47 (4th ed. 1983).

The concept of the Tax Expenditure Budget has been criticized. Its opponents argue that the budget is presented as if all income belonged to the federal government and that which it permits one to keep is a form of largesse from the central authority. ${ }^{48}$ This view misstates the purpose of the budget, for what it demonstrates is the gap between a comprehensive income tax base more nearly consistent with the Haig-Simons formulation and the tax law as it actually functions. Perhaps a more palatable view of the Tax Expenditure Budget would be to give it another title such as "Differences in Revenue by Categories between a Comprehensive Tax Base and the Congressionally Established Tax Base of the Internal Revenue Code." A cursory review of Table 8 will demonstate the significance of these differences and the difficulty of seeking legislation to eliminate them.

48. See Bittker, The Tax Expenditure Budget-A Reply to Professors Surrey and Hellmuth, 22 Nat'L Tax J. 538 (1969); Kristol, Taxes, Poverty and Equality, 37 PUB. INT. 3, 14-15 (1974); McIntyre, $A$ Solution to the Problem of Defining a Tax Expenditure, 14 U.C.D.L. Rev. 79 (1980); Surrey \& McDaniel, The Tax Expenditure Concept: Current Developments and Emerging Issues, 20 B.C.L. REv. 225 (1979). 


\section{IX}

\section{Tax Legislation in the Reagan Era}

\section{A. Economic Recovery Tax Act of 1981 (ERTA)}

In his first presidential campaign President Reagan proposed reducing the size of government and reducing the tax burden on citizens. The Economic Recovery Tax Act of 1981 (ERTA) ${ }^{49}$ was in large measure a fulfillment of the President's commitment. This legislation was estimated to produce a reduction in revenue of about $\$ 750$ billion for the years 1981-1986.50 The principal items accounting for almost $\$ 700$ billion $^{51}$ of this amount were: (1) the phased-in rate reductions, ${ }^{52}$ including the deduction for two-earner married couples; ${ }^{53}$ (2) indexing; ${ }^{54}$ and (3) the accelerated cost recovery system, including investment credits. ${ }^{55}$ This last item represented a major move toward a consumption system by permitting liberal expensing of certain capital assets and the allowance of credits against tax liability for such investments.

The President also sought a reduction in federal spending, which was creating a deficit before the revenue reductions became effective. Although spending would have to be drastically cut if the budget was to be balanced, the three largest items in the budget-social security, the defense establishment, and interest on the national debt-continued to increase. ${ }^{56}$ The deficit created by increased federal spending and diminishing revenues spurred Congress to try to change the tax system again to address the deficit and its concomitant problems.

\section{B. The Tax Equity and Fiscal Responsibility Act of 1982 (TEFRA) ${ }^{57}$}

Within the year following the enactment of ERTA, Congress sought to reverse some of the reductions in revenue enacted in 1981. Because of the presidential threat to veto any rate increases, Congress had to deal with

49. Pub. L. No. 97-34, 95 Stat. 173.

50. H.R. Rep. No. 215, 97th Cong., 1st Sess. 289, reprinted in 1981 U.S. Code Cong. \& AD. News $195,377$.

51. Id. at 290, 1981 U.S. Code Cong. \& Ad. News at 378.

52. I.R.C. \& 1 (Lawyers Co-op. 1984).

53. Id. \& 221 (Lawyers Co-op. Supp. 1985).

54. Id. \& 1(f) (Lawyers Co-op. 1984).

55. Id. $\S 168$ (Lawyers Co-op. Supp. 1985); id. $\S \S 46,48$ (Lawyers Co-op. 1984).

56. See UNItEd STATEs Budget IN BRIEF, supra note 37, at 67 , which displays estimates for fiscal years 1985 and 1986 as follows:

\begin{tabular}{lrrr} 
& 1985 & & 1986 \\
Social security and medicare & 257.4 & & 269.4 \\
Income security & 127.2 & & 115.8 \\
National defense & 253.8 & & 285.7 \\
Net interest & 130.4 & & 142.5 \\
$\quad$ Total listed items & 768.8 & 813.4 \\
All budget outlays & 959.1 & 973.7 \\
\hline \multicolumn{1}{c}{ Percent to total } & $80 \%$ & $\mathbf{8 3 . 5 \%}$
\end{tabular}

57. Pub. L. No. 97-248, 96 Stat. 324. 
closing loopholes, tightening enforcement, and deferring the phasing in of certain capital recovery provisions. Of the $\$ 750$ billion revenue reductions through fiscal 1986 enacted in ERTA, Congress proposed to recapture about $\$ 150$ billion through 1986.58 About $\$ 65$ billion of this amount was represented by amendments affecting capital cost recovery, withholding on interest and dividends, and other compliance safeguards.

By midsummer of 1983 the organized opposition to interest and dividend withholding had become so intense that, despite appeals by the President, Secretary of the Treasury, and the Chairman of the Senate Finance Committee, interest and dividend withholding was scuttled. ${ }^{59}$ Therefore, TEFRA's recapture of the ERTA reductions in revenue had to be revised downward by about $\$ 15$ billion.

\section{The Treasury Proposal of 1984}

In President Reagan's State of the Union message of January 1984, he called upon then Secretary of the Treasury Donald Regan to develop a major overhaul of the tax system by December 1984. The Treasury's proposals are contained in the three-volume work: Tax Reform for Fairness, Simplicity, and Economic Growth, ${ }^{60}$ otherwise known as Treasury I. The national policy objectives reflected in this document clearly constituted a reversal of the trend toward a consumption system and a return to an accretion system.

The document proposed an expanded tax base as explained under the accretion system, but with certain principal exceptions: unrealized gains and losses in taxpayer's net assets and income, gains, and losses attributable to the taxpayer's vested interests in qualified plans would not be recognized.61 Deductions for consumption expenditures, however, such as personal interest, state and local taxes, and charitable contributions would be limited or eliminated altogether. ${ }^{62}$ Investment tax credits would be eliminated and capital cost recovery would be based on real economic depreciation rather than the accelerated methods. ${ }^{63}$ Various special industry preferences would no longer be available. ${ }^{64}$ Additionally, Treasury I rejected the VAT in favor of the comprehensive income tax, although it acknowledged the VAT as a potential source of major revenue. ${ }^{65}$ This document represented a nearly ideal proposal for a comprehensive income tax base.

58. H.R. Rep. No. 760, 97th Cong., 2d Sess. 691, reprinted in 1982 U.S. Code Cong. \& Ad. News $1190,1454$.

59. I.R.C. \& 3451, repealed by Interest and Dividend Tax Compliance Act of 1983, Pub. L. No. 98$67,8102(a), 97$ Stat. $369,369$.

60. U.S. Dep't of the Treas., Report to the President: Tax Reform for fairness, Simplictry, and Economic Growth (1984) (in three volumes, Vol. 1, Overview; Vol. 2, General Explanation of the Treasury Proposals; and Vol. 3, Value-Added Tax) [hereinafter cited as Treas. REPORT].

61. These items are omitted from the detailed proposals, and, therefore, it must be assumed that they were considered and rejected for proposed change.

62. 1 TREAS. REPORT, supra note 60 , at 77-84.

63. Id. at 105-09.

64. Id. at $125-44$.

65. 3 TREAS. REPORT, supra note 60 , at 1 . 


\section{The President's Proposal of May 1985}

Following the release of Treasury I, various interest groups consulted with the Treasury and the President, urging that proposals for tax reform not go so far. Accordingly, under new Secretary of the Treasury Baker, a second publication, The President's Tax Proposals to the Congress for Fairness, Growth, and Simplicity, ${ }^{66}$ was released. It reflected a substantial retreat from the positions of Treasury I; preferences and shelters were restored and the efforts toward achieving a comprehensive base were diluted. ${ }^{67}$

President Reagan campaigned vigorously for the adoption of this proposal. The principal revenue gains and $\operatorname{losses}^{68}$ contained in it as projected for the fiscal year 1988 were:

Fiscal Year 1988

REDUCTION IN REVENUES

(IN BILLIONS)

Rate reductions for individuals, increase in zero bracket and exemption deduction amounts

Rate reductions for corporations

$\$ 104.6$

Net effect of allowing dividends paid deduction

Total-principal items of reduction

$\$ 146.7^{69}$

Fiscal Year 1988

GaINS IN REVENUES

(IN BILLIONS)

Repeal deduction for state and local taxes

Taxing real economic income, the principal items of which consist of substituting a modified capital cost recovery system for the accelerated cost recovery system of ERTA, the repeal of the investment credit, and modification of the capital gains benefits

Requiring more taxpayers to conform to an accrual system of accounting

Recapture of previous deductions under the accelerated cost recovery system

38.8

$\frac{20.7}{\$ 105.4^{70}}$

Miscellaneous other revenue gains projected for fiscal year 1988 would still leave a shortfall in revenue of $\$ 7.3$ billion. ${ }^{71}$ The proposal for a new capital

66. Pres. Proposals, supra note 29.

67. A chart explaining the difference in tax treatment of items in the two reports may be found in Pres. Proposals, supra note 29, at 26-30 (summary).

68. See id. at 453-61.

69. Taken from Pres. Proposals, supra note 29, at 453-61 (app. C).

70. Id.

71. Id. at 461 . 
cost recovery system and the elimination of the investment tax credit indicate the Reagan Administration's willingness to reverse the trend toward a consumption system enacted in ERTA. Moreover, other major modifications listed above, such as the limitation of the capital gains benefits, the imposition of the accrual system on more taxpayers, and the denial of deduction for nonbusiness related state and local taxes, are all indicative of a greater acceptance of the principles of an accretion system. ${ }^{72}$

\section{$\mathrm{X}$}

\section{Conclusion}

Treasury I, if enacted into law, would have provided a comprehensive tax base more nearly consistent with a pure accretion system. Such a reform measure would have been a fair system judged by the criterion that taxes ought to be imposed on the basis of the taxpayer's ability to pay. A broad based consumption system is arguably the fairest system based on the criterion of standard of living; that is, those who consume more in proportion to total income pay more than those who forego consumption to save and invest.

The President's proposals (Treasury II) do not advance either system; once again we are facing proposals for a hybrid. Moreover, the enormity of the deficit and the national debミ suggests the need for supplemental taxes no matter what legislative changes are made in the income tax. The best prospect for supplemental revenue would seem to be a broad based VAT with appropriate credits against the income tax for the VAT paid by lower income families. ${ }^{73}$

72. The willingness on the part of Treasury officials in the preparation of both Treasury $I$ and Treasury II (Reagan I) to espouse a broadening of the income base and the elimination or modification of deductions for consumption expenditures, or living expenses, is a recognition of the basic fairness and vitality of a comprehensive income tax system.

73. As this issue goes to press, the House of Representatives has approved a new Internal Revenue Code of 1985 which would further dilute the base-broadening efforts of Treasury I and the President's proposals. 


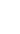

